\title{
The WebQuest Model for Inquiry-based Learning Using the Resources of the World Wide Web
}

\author{
Harriet G. Taylor \\ Dept. of Educational Leadership, Research, and Counseling, Louisiana State University, Baton \\ Rouge, LA 70803, USA \\ taylor@lsu.edu
}

Keywords: learner-centred learning, teacher education

\begin{abstract}
The WebQuest model of organising classroom learning inquiries involving resources on the Internet has become an important component of technology teacher education at one university. Educators create realistic, challenging learning environments that are related to their own curriculum and students. Through WebQuests, they practice guiding and directing leaming rather than prescribing it. The WebQuest model has flexibility as well as structure. It allows for diversity and co-operation as well as creativity. As a result of the WebQuest development activity, educators are empowered and connected with each other and turned on to active learning that is facilitated by technology.
\end{abstract}

\section{INTRODUCTION}

The World Wide Web has opened up a global classroom full of resources and challenges for students and educators. Many educators are quick to recognise the potential of the Web but are equally quick to realise the complexity of the Web and its resources. Educators must learn to structure classroom activities that include Web investigations so that students can use online time wisely and productively. At the same time, many Web-oriented projects must be defined in such a way as to allow for great diversity in learners and in learning outcomes so that all students can benefit from Webbased activities. 
One method of organising classroom activities is through WebQuests, inquiry-based learning activities in which some or all of the information that students interact with comes from the Internet. WebQuests can involve short-term, three or fewer class periods, of work or be more extensive. They often involve collaboration and are multidisciplinary.

\section{THE WEBQUEST MODEL}

The concept of WebQuests was introduced by Bernie Dodge of San Diego State University in 1995 (Schrock 2000). According to Dodge, "A WebQuest is an inquiry-oriented activity in which some or all of the information that learners interact with comes from resources on the Internet" (Dodge 1998). A WebQuest includes a specific, clear task or quest for students often working collaboratively. The WebQuest itself is organised through the development of a Web site with teacher and student pages. Each page contains the six main WebQuest components needed to introduce, organise, and direct the inquiry. These include an introduction, the task, the process, the information sources, evaluation, and conclusion (Dodge 1998, Mautner 1997). WebQuests are usually inquiry-oriented and involve student products demonstrating synthesis of concepts or other representations that illustrate higher-order thinking skills and learning.

The Web contains a number of excellent resources on the development of WebQuests as well as example quests. Bernie Dodge's WebQuest site (Dodge 2000) contains a wealth of resources. These include samples organised by discipline (Dodge 2000), sample templates for quest construction, sample rubrics for evaluation (Dodge 1999a), and discourse on the nature of the model itself (Dodge 1997, Dodge 1998). In fact, he uses his own model to teach about WebQuests by providing a WebQuest on WebQuests at the site. Kathleen Schrock (Schrock 2000) maintains an excellent teacher resource page with WebQuest links, including a link to a PowerPoint presentation on the WebQuest model. Tom March, who was also involved in the development of the model and many of the early examples, provides an online work (March 2000) which discusses the rationale of the model as well as pointers for those starting to develop WebQuests.

WebQuests provide an outstanding way of organising a learning activity. Sites such as those described above provide resources to help in the development of WebQuest learning activities. They also contain a wealth of proven, effective WebQuest activities allowing educators to share their work and expertise around the world. 


\section{USE IN TEACHER EDUCATION}

WebQuests have been used effectively in both pre-service and in-service teacher education at Louisiana State University. Prospective teachers are introduced to technology applications and technology supported learning via participation in collaborative WebQuests related to their curricular areas. Graduate education students, all experienced teachers, participate in WebQuests as well, but many also use the model for developing their own instructional units.

\subsection{Prospective teachers and WebQuests}

At Louisiana State University, groups of education students who are preparing to be teachers are introduced to the Web and technology-supported learning with WebQuests. For example, in March of 1999, a group of preservice mathematics and science teachers were introduced to Web-based learning during a five-hour session. In the morning, the educators were introduced the WebQuest model and to Power Point. They previewed samples of real quests and student products done by others. They were presented with a Rainforest WebQuest and told that they should organise themselves into teams of four to carry out the quest in the afternoon. At noon the students were united in their protests of unfairness. They had been given an unreasonable task that they would not be able to complete due to their limited technology skills and limited time to complete the project.

That afternoon, the students began work despite their reservations. Soon most were no longer upset but were excited and motivated. They were amazed at the wealth of resources on the Web and the amount that they learned about the rainforest. They worked together to produce masterpiece PowerPoint presentations incorporating information, graphics, and sounds from the Web. During the final part of the session, the students proudly shared their presentations with each other and they were truly impressed with themselves and what they had accomplished. They were confident that they could use WebQuest lessons that were developed effectively and they also began to brainstorm about ideas for their own WebQuests. They fully understood the benefits and power of technology-supported, collaborative learning and the teacher preparation that was needed to do it effectively.

\subsection{Graduate educators develop WebQuests}

WebQuests have proven to be exciting and useful alternatives to the traditional lesson plan approach to instructional organisation. Graduate education students at Louisiana State University have developed a collection 
of WebQuests that are now in use many places around the world. These can be found at the LSU WebQuest site (Taylor 1999). WebQuest development usually takes place over a six to seven week period. Students must follow a prescribed timeline of activities including topic and resource selection, page development, peer assessment and revision, and production of sample or actual student projects.

\subsubsection{Topic selection and resource identification}

The students are introduced to the WebQuest model. This includes presentation by the instructor and some sample WebQuests and student products. The students then do an abbreviated form of the WebQuest on WebQuests (Dodge 1999c) for their grade level. This exercise helps them identify the elements of good WebQuests and understand the importance of selecting appropriate curricular topics and resources for WebQuests

They then study the model and examples found at the WebQuest Page (Dodge 1999b, Dodge 2000) appropriate for their own content areas. Students discuss topics that would and would not make good WebQuests and brainstorm on ideas. Then students work in teams to determine the topic and goals of the quests they will develop. They search to be sure that a WebQuest on the same topic does not already exist. They are encouraged to develop quests of particular value to them as educators. That is, they should think about their curriculum and units that their students study and develop a theme that they can use with their classes.

Once they have identified one or more potential topics, the students then need to locate and examine resources. Often this is the point at which the critical decisions are made about the actual topic that will be developed. Students quickly find that some topics have many more Web resources than other topics and learn to identify areas that are and are not best served by Web research. They must the e-mail the professor within one week with a proposal of a topic. The professor then corresponds with them about their proposal until then have a plan that reasonably fits the WebQuest model.

\subsubsection{Development of WebQuest materials}

The students are instructed to submit a proposal for a short WebQuest, one that the target student population can complete in three class periods. In addition to developing the WebQuest, they must also develop sample student products or test the WebQuest with students and submit the actual student products. They are told that the time is critical. Once the proposal is accepted, the students have two weeks to develop the teacher page of the WebQuest on which they define all of the WebQuest components including 
the goals and products to be expected. The Dodge WebQuest model includes both a teacher page and a page just for the students. Often these are very similar with a little less formal information on the student page. The LSU students are given some flexibility on this. If they feel their teacher page is sufficient for students, they do not have to make a separate student page.

\subsubsection{Peer evaluation}

During class two weeks later, the students work in teams to review the quests of each other. They use a modified version of the draft rubric (Dodge 1999a) for evaluating WebQuests. This proceeds in two or more cycles depending on the size of the class. They first work with their own team to evaluate the quest of another group. Then at least one member of the team returns to their site to receive feedback and the others give feedback to the group that they reviewed. In the next cycle, students are paired with others who are not on their team, all following a prearranged rotation schedule developed by the professor. This has proven to be one of the most valuable components of the activity. Students get insights into their own work by critically looking at the work of others and they also benefit from discussing the merits of certain approaches with others not on their team. They must deal with knowing that things that seem very clear to them are confusing to others and make value judgements when they receive conflicting information from different review teams. Students are encouraged to continue the peer review informally as they refine their WebQuests so that their end product is educator and student friendly as well as substantive in content and scope.

\subsubsection{Sharing WebQuests and student products}

Two to three weeks later, the final WebQuests and student products are due. Students present their work and display their sample products. The depth of their work and learning is obvious and the scope and quality of the work is appreciated by all. Many students have said that the WebQuest sharing is one of the most valuable learning experiences they have ever had. They learn about many curricular areas, approaches to learning, and innovation. Frequently, topics that seem blatantly mundane and unexciting become magical when viewed with the student products. For instance, a middle school mathematics teacher and school counsellor developed a WebQuest on hurricanes (Birke and Pitchford 1998). The basic premise of the quest was fairly straightforward with a student product that described certain qualities of hurricanes. The middle school students decided to develop their own unique representation of their learning in a slide show presentation of a diary of a hurricane. It included birth, getting a name, 
growing up, teenage dreams of grandeur, and finally immortality. It displayed a grasp of the concepts in an engaging, almost humorous way, and brought immediate respect to two students who had been struggling in the class.

\subsubsection{Collection in a common site}

The final WebQuests are then collected on-line in a common site (Taylor 1999). Most are put on-line in temporary testing locations prior to completion as well. The students provide short blurbs for the listing and quests are grouped according to grade level.

\section{EXAMPLES}

The WebQuest model is one that is best appreciated by examples and practical experiences. Students can look at the examples the Dodge site (Dodge 1999b) or read about real examples in Maureen Yoder's article (Yoder 1999). It is important that teachers see the wide range of topics, tasks, and student products that can be included in WebQuests. This is illustrated by several examples developed at Louisiana State University.

Sadako and the Thousand Paper Cranes. This WebQuest for students in grades 3-5 is based on a well-known book by the same name and uses many Web sites devoted to Sadako, Japan, and the war. Students do a variety of interdisciplinary activities, including timelines, origami, writing based on research, map exploration, and cultural comparisons.

Life in Rural America During the 1800s. Middle school students investigate how people lived in the 1800 s. They rewrite a modern story as if it took place in the 1800 s using historically correct terms. They make PowerPoint presentations including music and graphics that depict the times.

The Titanic. Secondary students use an excellent Australian database to verify the reliability of two seemingly conflicting quotes about the Titanic disaster. They develop spreadsheet charts that illustrate their finds as well as presentations and written explanation of their charts.

\section{RESULTS}

The WebQuest model has proven to be an exciting and challenging part of the education curriculum at LSU. Educators have found the model and the development of effective WebQuests to be difficult but rewarding. In constructing their own WebQuests they have experienced the same joy in 
taking charge of their learning that their students do. They approach WebQuest development with far more enthusiasm than a traditional lesson plan assignment. Most are also eager to implement their products with real students and incorporate their WebQuests into their teaching.

The education students' WebQuest development activity is a structured learning activity. It includes several stages and checks. It includes instructor and peer feedback, design and investigation, and production and evaluation. In addition to producing the WebQuest, the students must also produce sample student products, similar to those that they might expect from the WebQuest, or they can field test the WebQuest with a group of students and turn in results and actual products.

The WebQuests that have been developed are archived at a single Web site (Taylor 1999) and reached through the San Diego State site. This has led to many interesting encounters with others around the world. Some of the LSU WebQuests been used for professional development workshops around the nation and have been well acclaimed by others. Thus the WebQuest development activity has enriched the professional lives of the education students in ways that were unimaginable to most of them.

\section{ELEMENTS OF GOOD WEBQUESTS}

Repeated experience as well as research of others had led to an appreciation of several critical elements that are needed for successful WebQuest lessons. These include:

1. Simplicity. Often educators tend to get too involved in using many technologies, sites, and resources. A simple, doable approach that can be achieved by most educators is best.

2. Design. WebQuests are implemented as live Web sites. Attractive sites that are easily navigated and current are essential.

3. Resources. The heart of the WebQuest is the resources. Thus educators developing WebQuests must locate excellent resources from reliable sources which have a high potential to remain online over time.

4. Organisation. WebQuests must follow a set pattern, but they still must be well organised. Activities must be clear and simply stated.

5. Visualisation. The first comment often heard when educators evaluate good WebQuests is "I can see the kids doing that!" Educators need to be able to visualise the activities and products before using the WebQuest.

6. Diversity. WebQuests should allow for creativity and diversity in students and student products. This often comes in the form of describing quest teams where each student has a role or in the form of identifying a range of possible student products. 
7. Quest element. WebQuests are effective when they actually are presented more as quests than simple chore lists. It is often better to leave some things to student imagination and creativity rather than being too prescriptive about products and assessment.

8. Curricular link. WebQuests are designed for real students and teachers. The topics must be aligned with curricular goals and outcomes that teachers identify and value.

Developing a good WebQuest is an involved process. It requires knowledge of classroom practice, student abilities, and content as well as technology tools.

\section{PROBLEMS AND ISSUES}

Development of sound WebQuests is not a simple process. WebQuests are always works in progress that need care, maintenance, and updating over time. Several problem areas or issues have evolved.:

1. Maintenance of site. The students develop the WebQuests as part of a course. Some take ownership of their work and responsibility for updating links and maintaining their sites after the class. There are issues with the ownership of the work and mechanisms to ensure the continued maintenance of the quests on our local site.

2. Central location for quests. Web space for the quests is an issue that has been addressed several ways at LSU. A central WebQuest page has been developed with links to all the sites. At one time, all the quests were housed in a common space. Now students store their quests in their own assigned space that they manage. Each method has merits and drawbacks. No real ideal solution has been found.

3. Field testing/validation. Testing and validation, particularly of the educational value of the products is an important component of WebQuest development. When possible, the educators who develop the WebQuests test them with their students. The feedback received from actual use is different that of peer review. Often developers substantially revise their work to have much more realistic tasks and simple, clear directions when field-testing is involved. Continuous testing and validation during development is essential to the development process.

4. Student products. A WebQuest must have some expectations of students as a result of the quest. This is usually a product of some type, often collaboratively developed, which reflects synthesis of concepts and ideas. The product may or may not involve technology, but often does involve the use of technology and sharing the findings with other audiences. It is essential that the developers also deal with the student product issue. That 
is, the developers must also produce or see actual products representative of their students and determine how to assess these products. The student product component is easily the most provocative and rewarding part of the experience for most students.

5. Development time. One could take a WebQuest template and type in some information in a very short time. WebQuest development is not a simple task and takes a great deal of time for critical thought and evaluation. Students will perceive them as the instructor perceives and presents them. That is, they will give a WebQuest time and energy based on the importance placed on it by the professor in terms of time and interaction. Thus, others planning WebQuest development activities must carefully structure the activity and allow time for the WebQuest to evolve and flourish with the students.

6. Lesson plan versus WebQuest. In the course, students preview countless sites that provide well-organised lesson plans. For most of the students, WebQuests are different. There is a sense of adventure in writing the WebQuest so that it encourages and invites exploration or learning rather than dictates it. The professor has rarely seen a student become excited over developing a lesson plan. She has seen students totally consumed with their WebQuests and has found it to energise many educators as they accomplish goals well beyond their imagination.

\section{CONCLUSIONS}

The WebQuest model has proven to be an excellent organisational model for teacher education at one university. Students preparing to be teachers participate in collaborative WebQuests as a way of learning about inquiryoriented learning and technology applications. Experienced educators practice their skills at guiding or directing learning rather than prescribing it. The WebQuest model is one that has great potential for teachers and teacher educators. It is a proven model that has flexibility as well as structure. It allows for diversity and co-operation, structure and imagination. WebQuests represent one of the many ways in which we must restructure learning and the teacher education process if we are to prepare educators to meet the challenges of the technology-rich, connected classrooms that will characterise education in the very near future. 


\section{REFERENCES}

Birke, M. and Pitchford, T. (1998) Hurricane WebQuest.

[asterix.ednet.lsu.edu/ edtech/webquest/canequest.htm] 15.8.2000.

Dodge, B. (1997) Some Thoughts About WebQuests.

[edweb.sdsu.edu/courses/edtec596/about_webquests.html] 15.8.2000.

Dodge, B. (1998) WebQuests: A Strategy for Scaffolding Higher Level Learning.

[edweb.sdsu.edu/webquest/necc98.htm] 15.8.2000.

Dodge, B. (1999a) A Draft Rubric for Evaluating WebQuests.

[edweb.sdsu.edu/webquest/webquestrubric.html] 15.8.2000.

Dodge, B. (1999b) Matrix of Examples. [edweb.sdsu.edu/webquest/matrix.html] 15.8.2000.

Dodge, B. (1999c) WebQuest about WebQuests.

[edweb.sdsu.edu/webquest/webquestwebquest.html] 15.8.2000.

Dodge, B. (2000) The WebQuest Page. [edweb.sdsu.edu/webquest/overview.htm] 15.8.2000.

March, T. (2000) WebQuests \& more. [www.ozline.com/learming/index.htm] 15.8.2000.

Mautner, C. (1997) Using WebQuests in the K-12 Classroom. School Web Page Design Guide, Classroom Connect, Inc., Lancaster, PA, pp. 13-16.

Schrock, K. (2000) WebQuests in Our Future: The Teacher's Role in Cyberspace. [discoveryschool.com/schrockguide/webquest/webquest.html] 15.8.2000.

Taylor, H. (1999). LSU WebQuests. [asterix.ednet.lsu.edu/ edtech/webquest] 15.8.2000.

Yoder, M. (1999) The student WebQuest. Learning and Leading with Technology, 26(7), pp. 6-9, 52-53.

\section{BIOGRAPHY}

Harriet G. Taylor is professor of education at Louisiana State University. Her research interests include telecommunications and distance education, human factors, retraining programs, technology integration into K-12 classrooms, technology supported mathematical models, computer science curricula, programming languages, teaching methodology, technology standards and accreditation, publishing on the World Wide Web. 